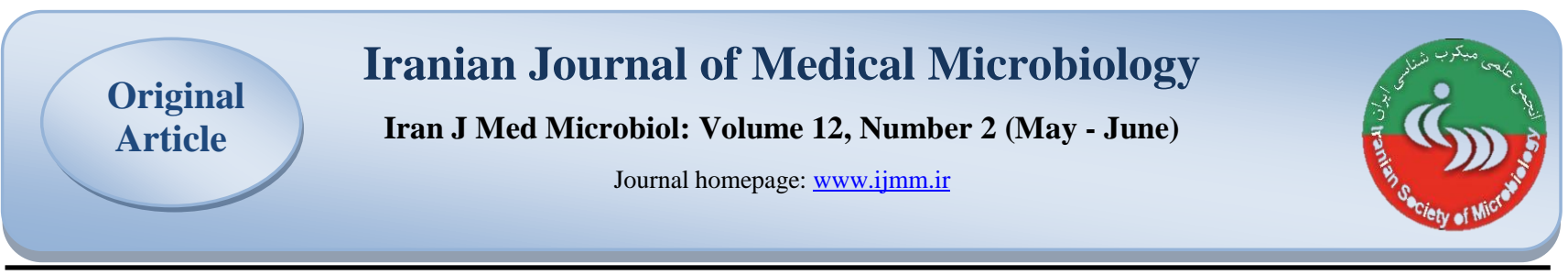

\title{
Isolation and Identification of Lactobacillus salivarius from Buffalo Milk and Evaluation of Its Antimicrobial Activity
}

\author{
Elham Hossein Alipour', Karim Mardani², $\underline{\text { Mehran Moradi }}{ }^{2}$
}

1. Department of Microbial Biotechnology, Faculty of Basic Science, Payam Noor Univercity, East of Tehran, Tehran, Iran

2. Department of Food Hygiene and Quality Control, Faculty of Veterinary Medicine, Urmia University, Urmia, Iran

\section{Article Information}

\section{Article history:}

Received: $2017 / 05 / 28$

Accepted: 2018/04/29

Available online: 2018/06/30

\section{Article Subject:}

Food Microbiology

IJMM 2018; 12(2): 96-106

Corresponding author:

\section{Mehran Moradi}

Assistant Professor in Food

Hygiene, Department of Food

Hygiene and Quality Control,

Faculty of Veterinary

Medicine, Urmia University,

Urmia, Iran

Tel: 044-31942633

Email:

m.moradi@urmia.ac.ir

Use your device to scan and read the article online

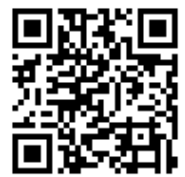

\section{Abstract}

Background and Aims: Lactobacillus salivarius is a well-known probiotic bacterium, which is commonly isolated from gastro-intestinal tract of human and animals. The objectives of the present study were isolation, molecular detection and antimicrobial characterization of $L$. salivarius from buffalo's raw milk.

Materials and Methods: A total number of 20 buffalo milk samples were collected aseptically from traditional buffalo farms in Urmia city, Iran. Milk samples were cultured and incubated on MRS agar, then suspected colonies were primarily determined according to their appearance and biochemical characteristics. Bacteria species were confirmed by polymerase chain reaction accompanied by restriction fragment length polymorphism (PCR-RFLP) and nucleotide sequencing of $16 \mathrm{~s}$ rRNA gene. Antimicrobial activity of $L$. salivarius against pathogenic bacteria including Listeria monocytogenesis, Escherichia coli, Salmonella typhimurium, and Staphylococcus aureus was examined using agar-spot and agar-disk diffusion methods. Cell surface hydrophobicity of $L$. salivarius was also investigated according to microbial adhesion to xylene and toluene hydrocarbons.

Results: From 60 suspected colonies which were selected according to phenotypic characteristics, 23 colonies were confirmed as lactic acid bacteria based on the molecular identification. Only one isolate belonged to $L$. salivarius. The antimicrobial activity results showed a significant growth inhibitory effect of $L$. salivarius on pathogenic bacteria comparing to standard bacteria. L. salivarius had the most inhibitory effect on $S$. aureus while it had the least inhibitory against $S$. typhimurium. The hydrophobicity of $L$. salivarius to xylene and toluene were $55.3 \%$ and $55.6 \%$ respectively.

Conclusions: Based on the results, the frequency of the Lactobacillus genus $s$ was very low in buffalo milk. In addition, isolated $L$. salivarius had strong antimicrobial activity against pathogenic bacteria.

Keywords: Buffaloes, Lactobacillus salivarius, Antimicrobial Capacity, Hydrophobicity, Molecular Diagnostics, Milk.

Copyright @ 2018 Iranian Journal of Medical Microbiology. All rights reserved.

How to cite this article:

Hossein Alipour E, Mardani K, Moradi M. Isolation and Identification of Lactobacillus salivarius from Buffalo Milk and Evaluation of Its Antimicrobial Activity. Iran J Med Microbiol. 2018; 12 (2): 96-106 


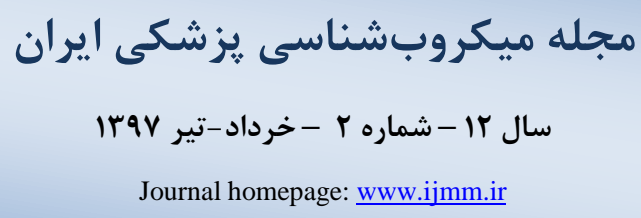

\section{جداسازى و شناسايى لاكتوياسيلوس ساليو/ريوس از شير كاوميش و}

ارزيابى اثرات ضدميكروبى آن آن الن

\section{الهام حسين عليِور'، كريم مردانى '، مهران مرادى'}

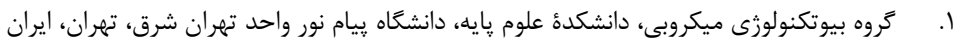

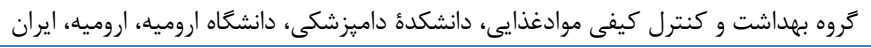

\section{جكيله}

زمينه و هدف: لاكتوباسيلوس ساليواريوس، باكترى بروبيوتيك شناختهشداى /ست كه از دستكاه كوارش انسان و حيوانات

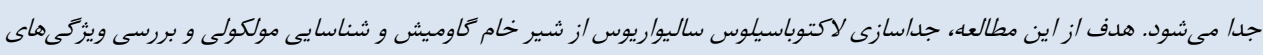

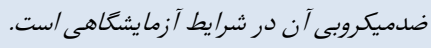

مواد و روش كار: تعداد • ب نمونه شير خام كاوميش از دامدارىهاى سنتى و صنعتى شهرستان اروميه تهيه و پِس از انتقال

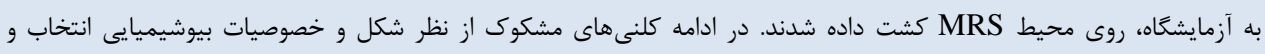

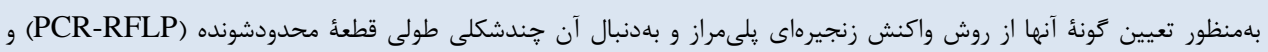

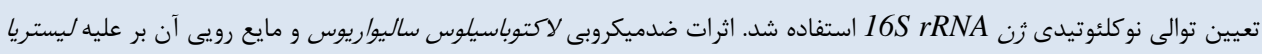

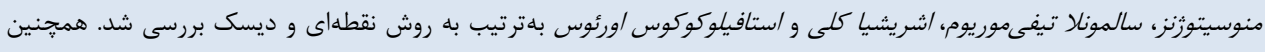

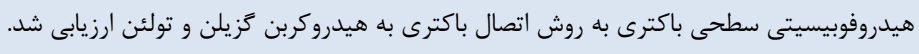

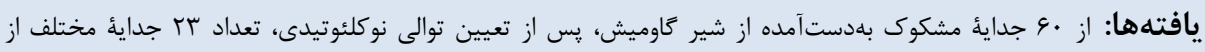

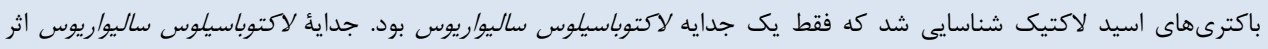

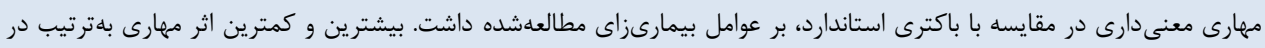

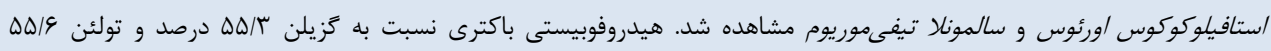
درصد كزارش شد. نتيجهكيرى: نتايج اين مطالعه نشان داد كه شيوع جنس لاكتوباسيلوس در شير كاوميش بسيار پايين است و لاكتوباسيلوس

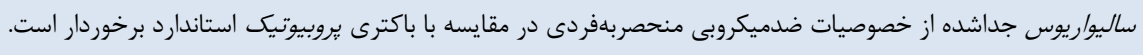
كلمات كليدى: كاوميش، لاكتوباسيلوس ساليواريوس، قدرت ضدميكروب، هيدروفوبيستى، تشخيص مولكولى، شير كبىرايت (C) حق جاب، نشر و استفاده علمى از اين مقاله براى مجله ميكروبشناسى بزنشى ايران محفوظ است.

اطلاعات مقاله

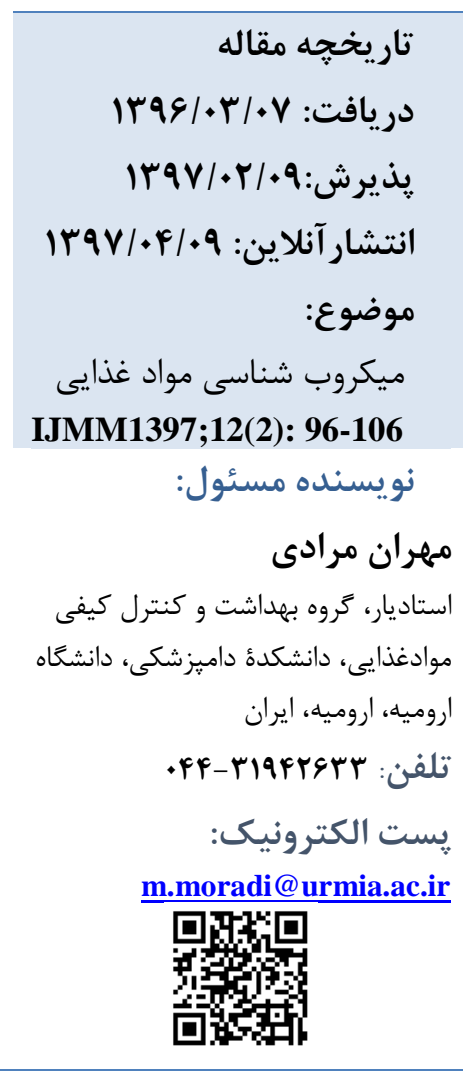

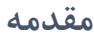

اززويلىساكاريد را رنيز دارند. تركيبى كه در مقاومت ميكرواركانيسم در مقابل فازها، حملات انگل ها و نيز تشكيل دئل بيوفيلم اهميت بسزايى داشته و موجب افزايش مقاومت باكترى مىشود. توليد اسيدلاكتيك از سوى اين باكترىها و در نتيجه كاهش pH محيط از جمله عواملى است كه منجر به عملكرد ضدميكروبى آنها مىشود. همجنين توليد تركيبات ضدميكروبى آنى متنوع كه در دو دسته تركيبات با وزن مولكولى یايين (يراكسيد هيدروزن، دىاكسيدكربن و دىاستيل) و وزن مولكولى بالا (نظير باكتريوسينها) قرار مى گيرند، از ويزگى هاى بارز اين باكترىها
باكترىهاى اسيدلاكتيك، فلور طبيعى دستخاه گوارش انسان و حيوانات بهشمار مىروند. در بسيارى از اكوسيستمهاى غذايى اين باكترىها بخش اعظمى از ميكروفلور غالب را تشكيل مى دههند و ممكن است بهصورت كشت كمكى و يا استارتر به محصولات غذايى نيز اضافه شوند. همجنين باكترىهاى اسيدلاكتيك عليه عوامل مختلف بيمارىزا يا غير بيمارىزا، طيف وسيعى از تركيبات ضدميكروبى را توليد مى كنند و لذا اين قابليت را دارند كه براى بيداي مقابله با اين نوع از عوامل ميكروبى استفاده شوند (ا، ؟). در شرايط خاصى، بسيارى از باكترىهاى اسيدلاكتيك توانايى توليد 
برخوردار است (سا). تاكنون از منابع مختلف براى جداسازى،

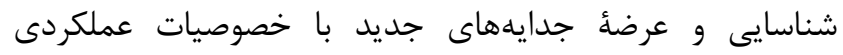

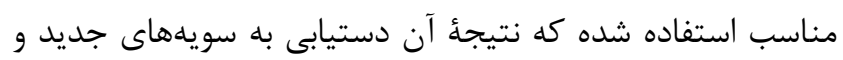

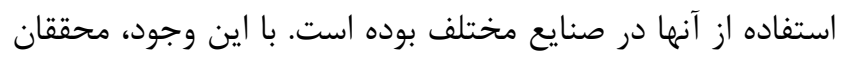

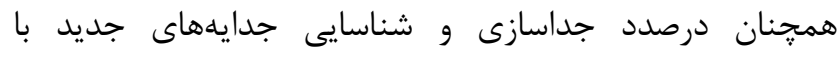
خصوصيات عملكردى منحصربلفرد هستند. تنوع باكترى دهاى اسيد

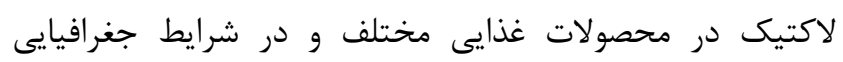

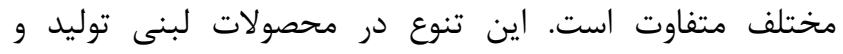

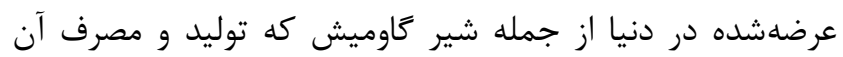

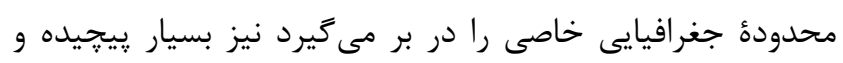

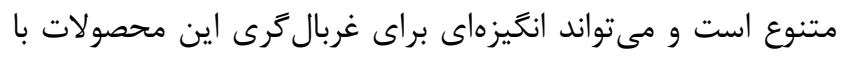
هدف دستيابى به سويههاى مناسب با خصوصيات عملكردى و ورئ

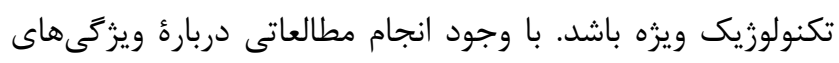

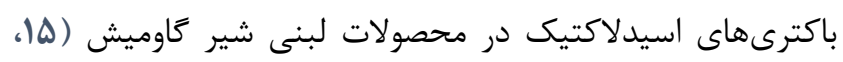

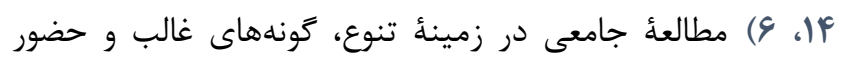

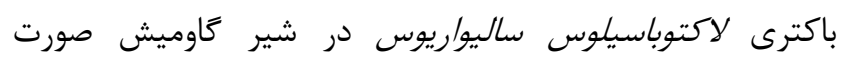

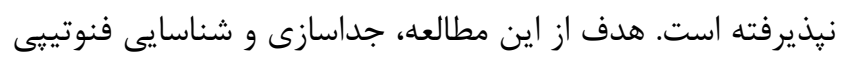

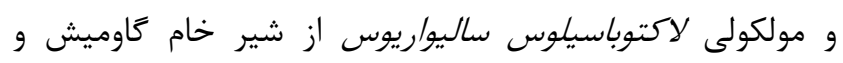

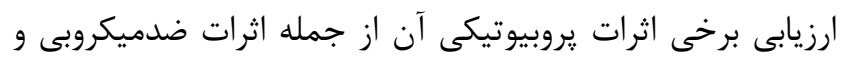

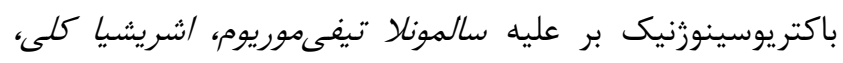

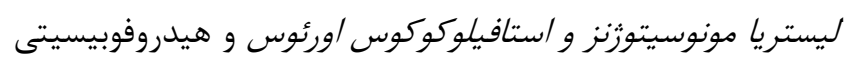
سطحى باكترى در شرايط آزمايشخاهى استو

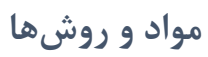

\section{نمونهبردارى شير خام تاوميش و شناسايى فنوتييى}

\section{جدايه هاى لاكتوباسيلوس}

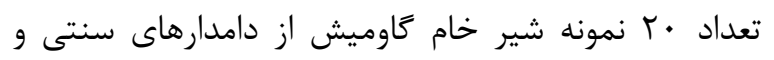

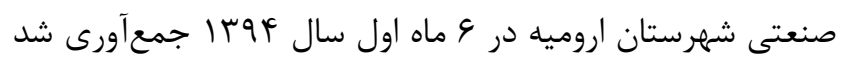
و سريعاً در داخل بطرىهاى استريل در شرايط سرد به آرمائ آزايشكاه

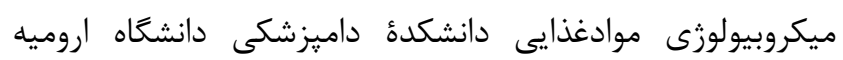

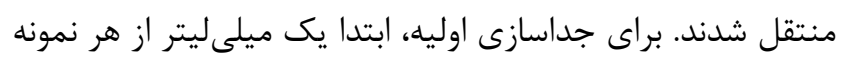

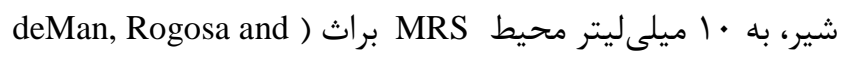
(شركت كيولب، كانادا) اضافه شد و هر نمونه در شرايط (Sharpe

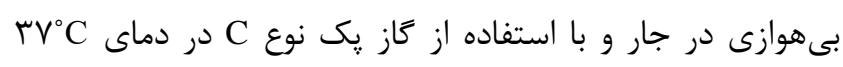

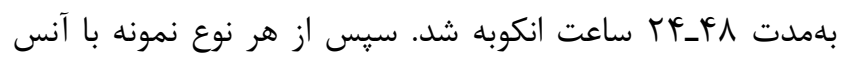

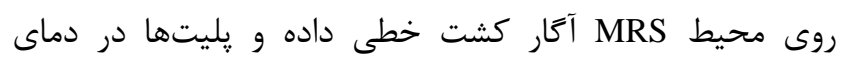

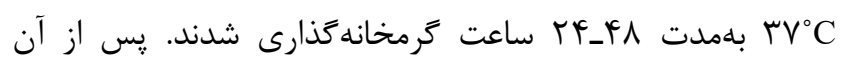

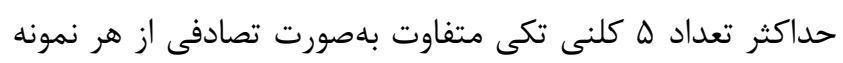

است. از سالها يِيش رابطؤ بين باكترىهاى اسيدلاكتيك و

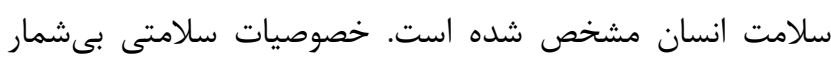

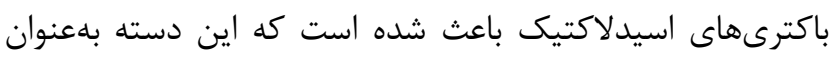

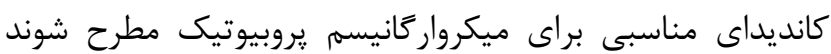

لاكتوباسيلوسها، باكترىهاى ترم مثبت ميلهاى شكل

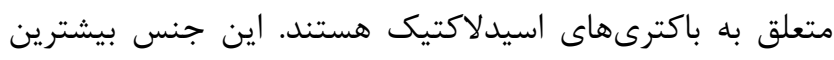

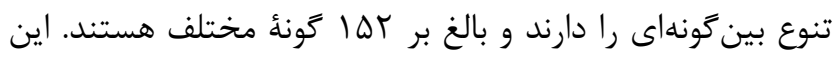

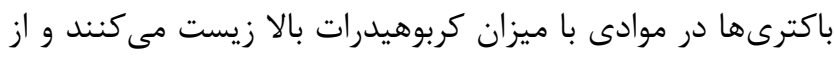

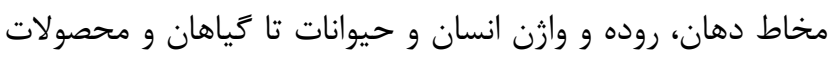

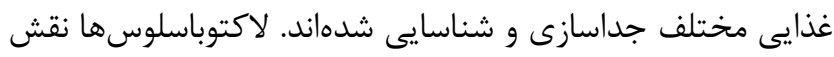
مهمى در توليد محصولات تخميرى سبزى، كوشت و محصولات

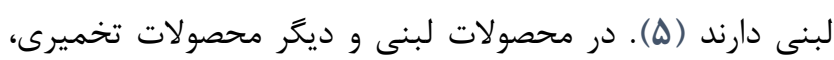

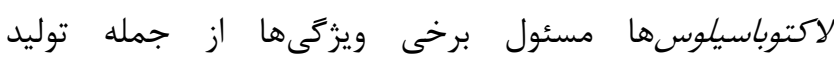

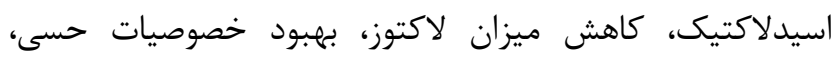
فيزيكى و شيميايى و كنترل عوامل بيمارىزا هستند. لذا لذا از كَونه

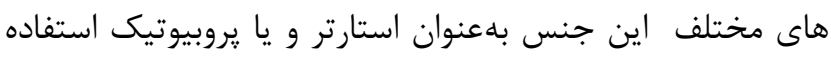

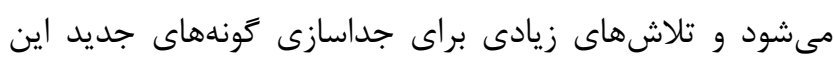
باكترى در حال انجام است (9).

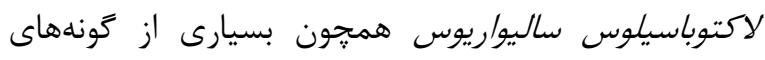

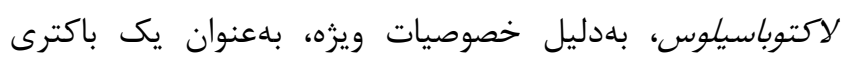

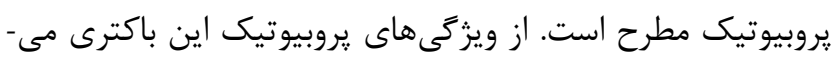

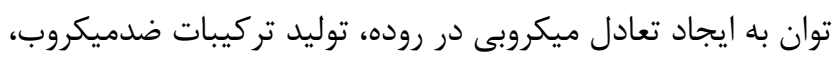

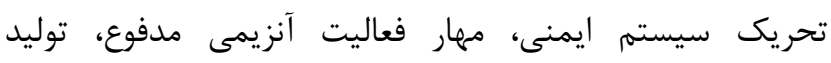

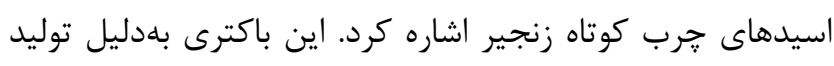

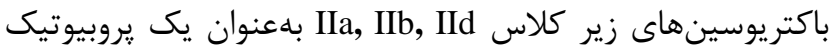

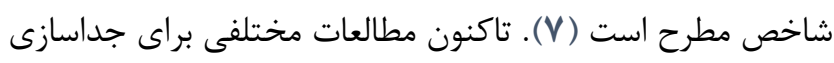

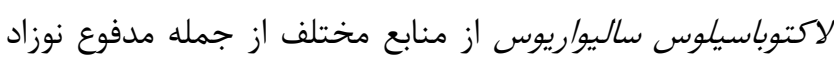

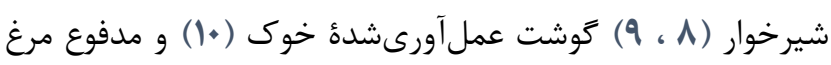
(II ، II) انجام شده است كه نتيجة اين تحقيقات جداسازى (1) سويههاى مختلف با ويزگى هاى عملكردى متفاوت است. در برخى إنى

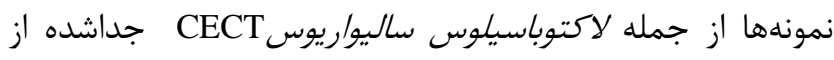

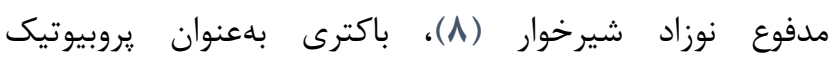
شناختهشده در سطح دنيا بهرهبردارى مىشود.

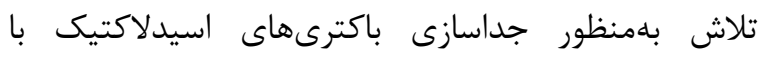

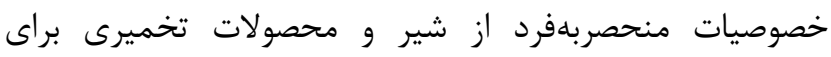

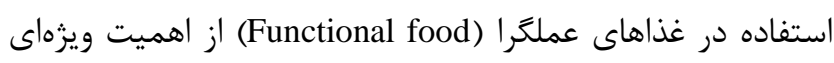


كنترل استفاده شدند. اين باكترىها از كلكسيون ميكروبى كروه

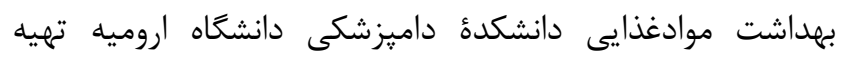
شدند. براى نكهدارى باكترىها در دماى

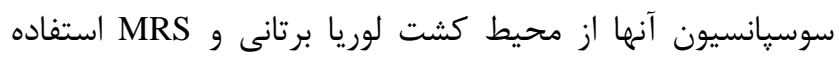

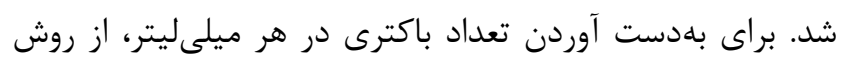

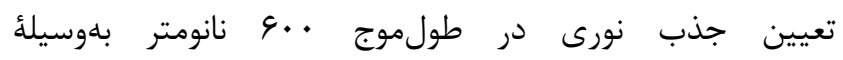
اسيكتوفتومتر و كشت باكترى استفاده شد.

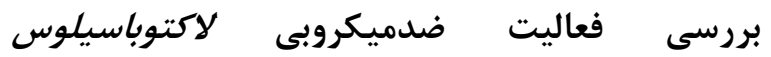

ساليواريوس برس

ويزگگ هاى ضدميكروبى لاكتوباسيلوس ساليواريوس به روش

نقطهاى و كشت دولايه انجام گرفت (19). براى اين منظور مقدار

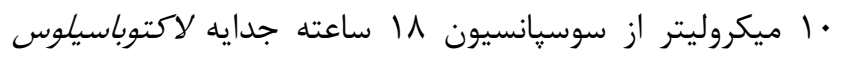

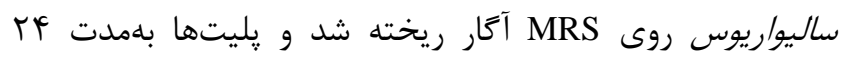

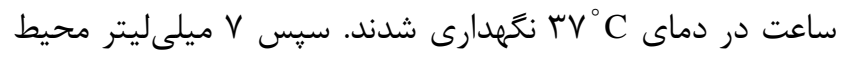

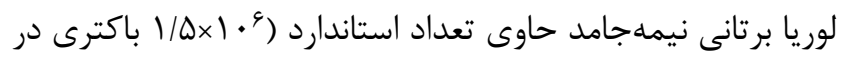

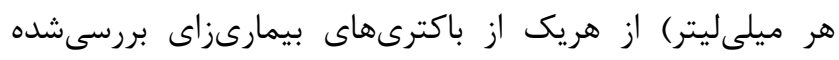

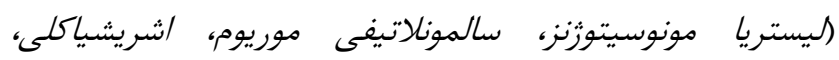

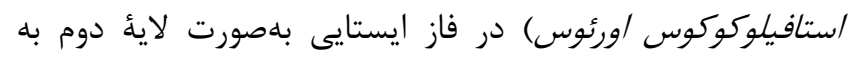

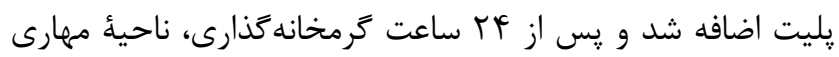

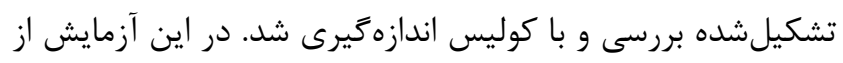

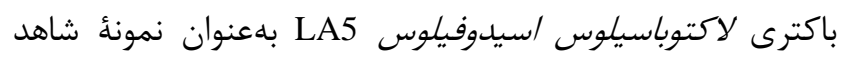
براى مقايسه با لاكتوباسيلوس ساليواريوس استفاده شد.

\section{بررسى توليد باكتريوسين لاكتوباسيلوس ساليواريوس}

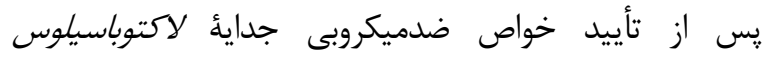

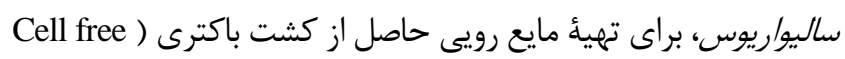

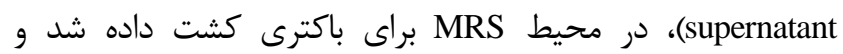

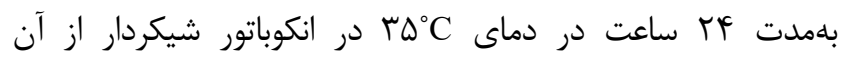

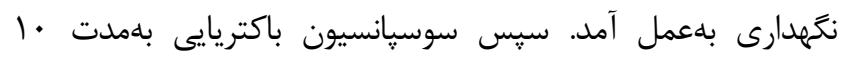

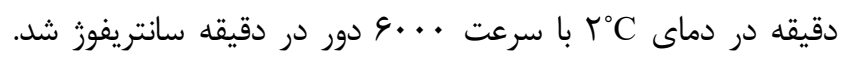

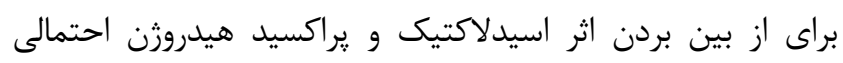

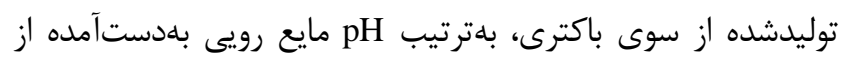

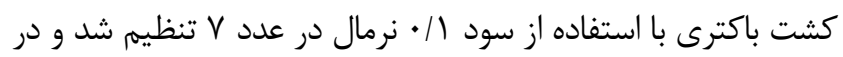

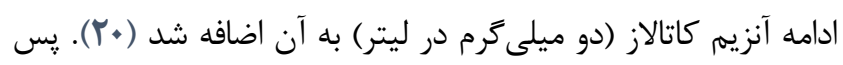

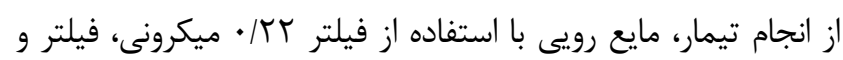

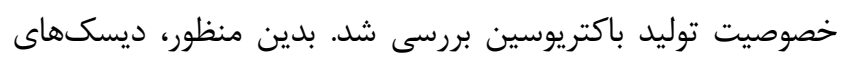

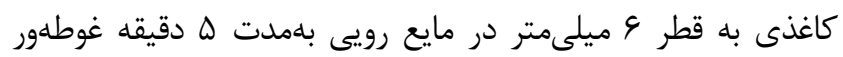

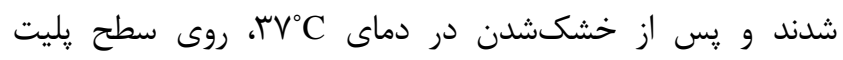
كشتدادهده با باكترىهاى بيمارىزاى منتخب قرار كرفتند. يس إن از

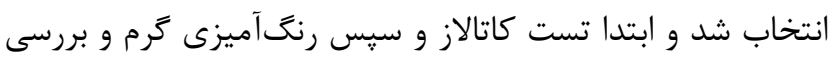

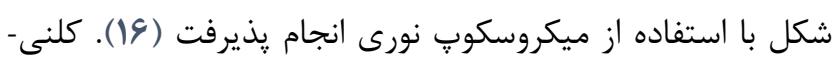

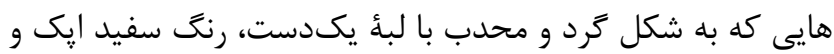

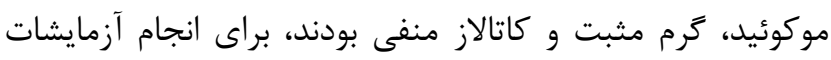

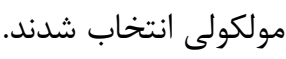

\section{شناسايى مولكولى لئى}

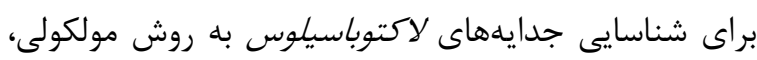

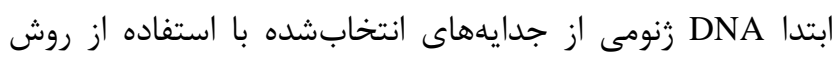

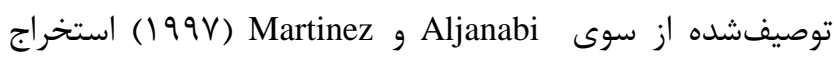

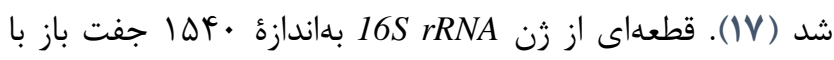

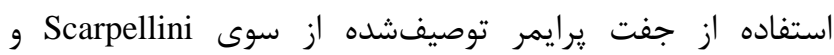

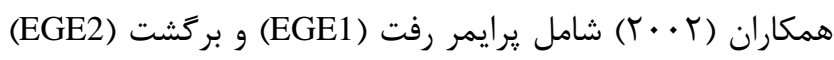

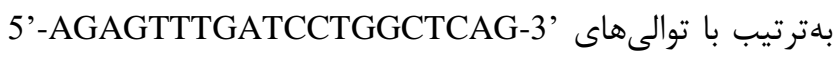

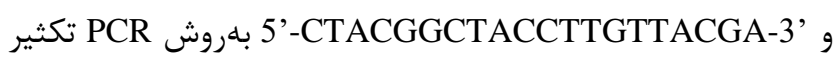

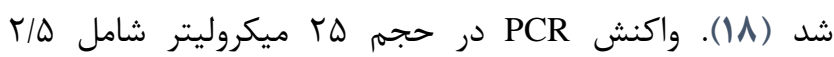

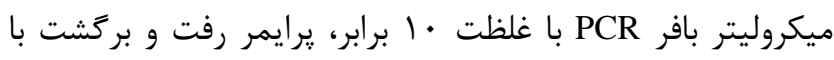

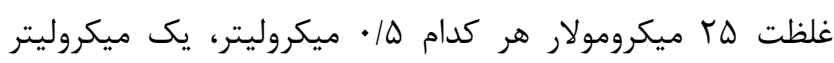

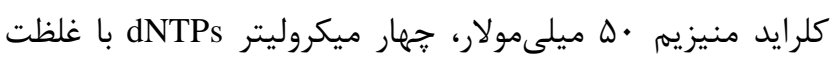
مقد آ ميلىمولار،

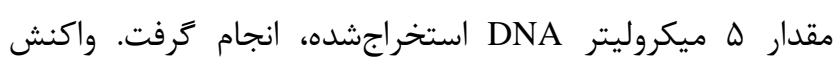

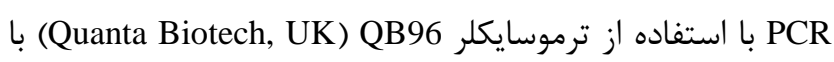

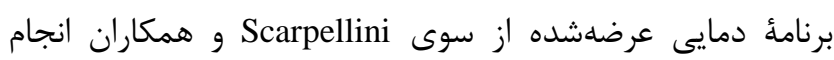

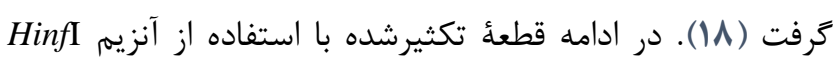

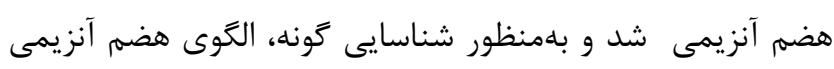
محصول PCR جدايههاى مختلف با الكوى هضم آنزيمى جدايه-

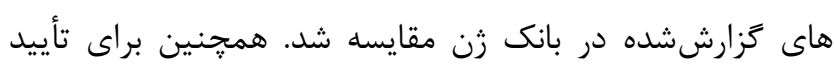

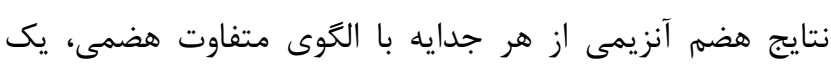

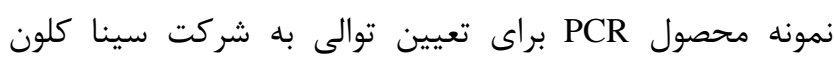

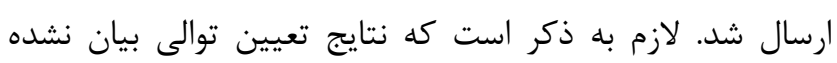

ارزيابى ويزگىهاى ضدميكروبى لاكتوباسيلوس ساليو/ريوس ارئس

\section{تهيد و آمادهسازى باكترىها}

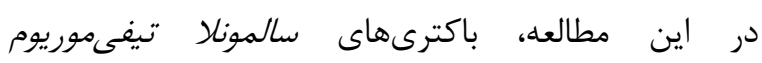

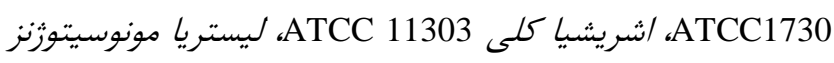
ATCC 19115

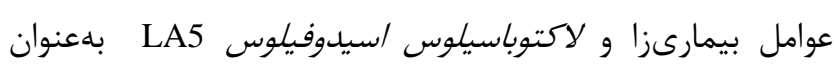


يافتنها شناسايى مولكولى باكترى هاى اسيدلاكتيكى

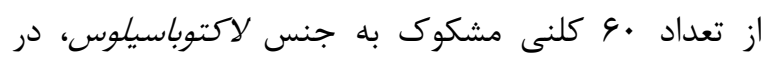

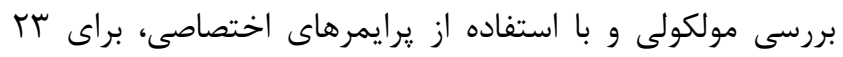

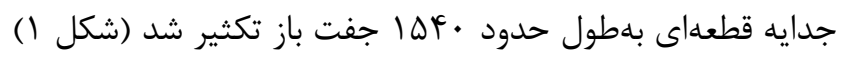

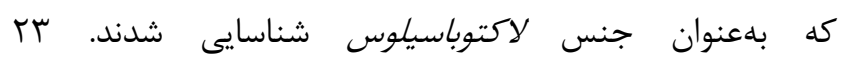

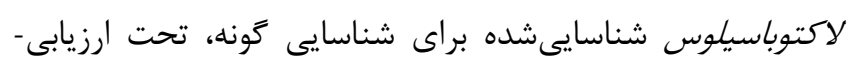

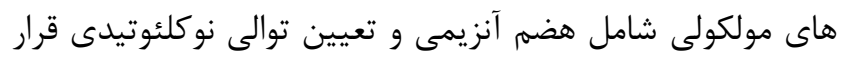

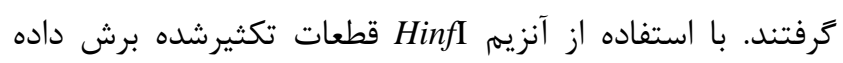

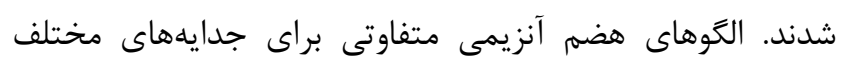

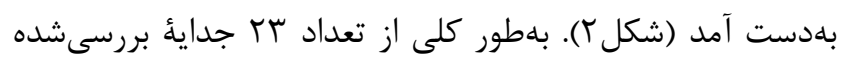

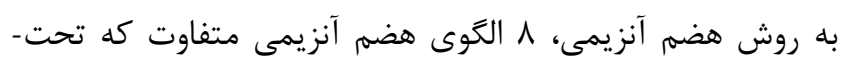

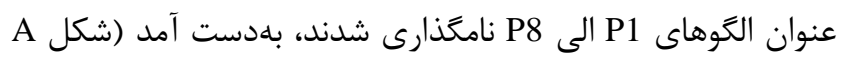

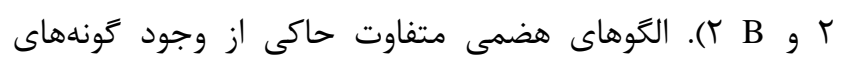

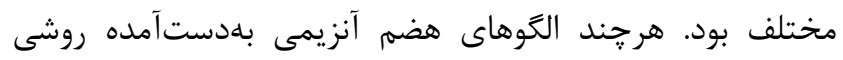

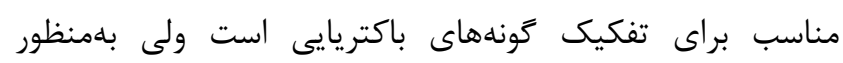

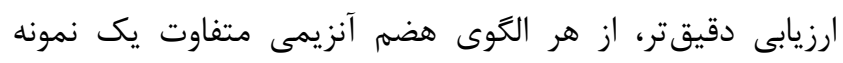

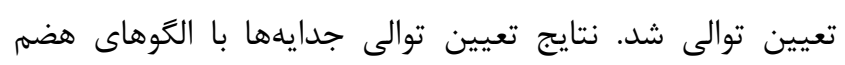

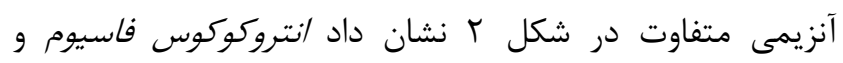

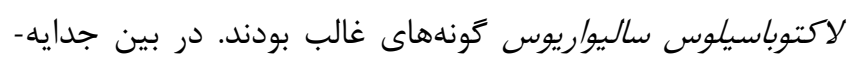

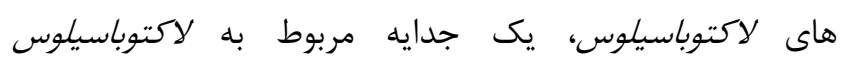
ساليواريوس كزارش شد.

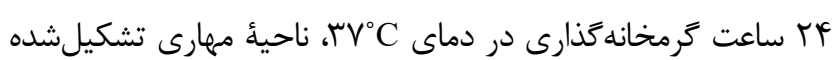

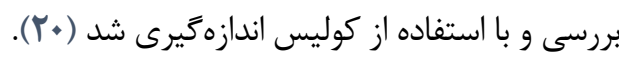

$$
\text { سنجش هيدروفوبيستى باكترى }
$$

براى سنجش هيدروفوبيستى سطحى باكترى، از هيدروفيسين باكتئ آزمون

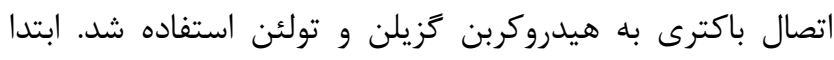

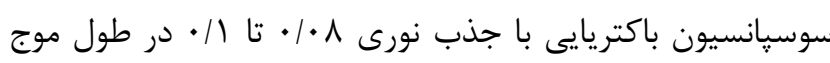
\&4.

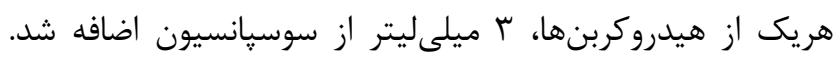

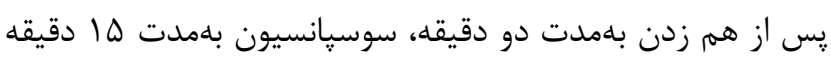

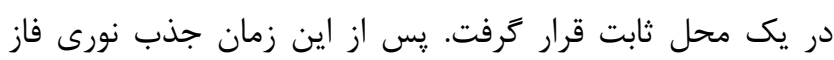

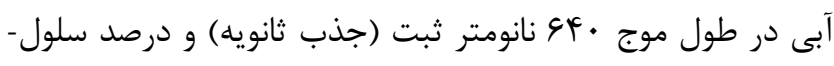

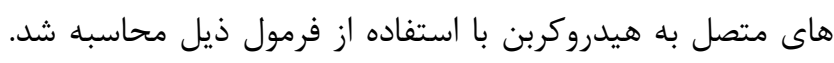

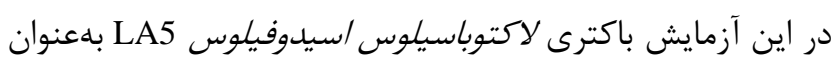

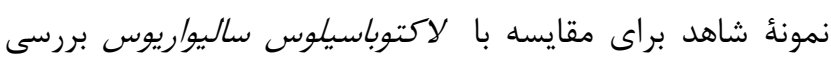

شد (آI). درصد سلولهاى متصل به هيدروكربن اكتان = جزذب اوليه

$$
\text { - جذب ثانويه/ جذب اوليه\{ × . 1. }
$$

$$
\text { روش آمارى }
$$

دادههاى بلددستآمده در اين تحقيق با استفاده از آناليز

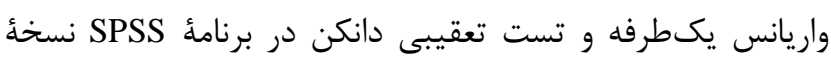

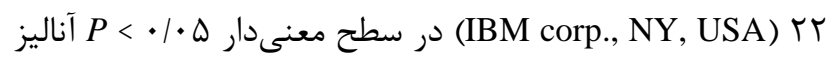

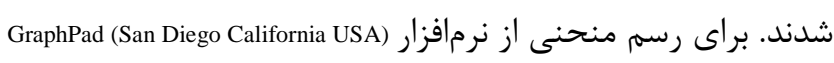

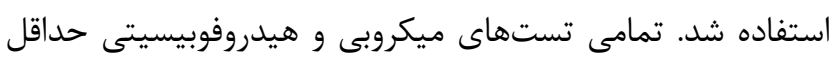
در سه تكرار انجام كرفتند.

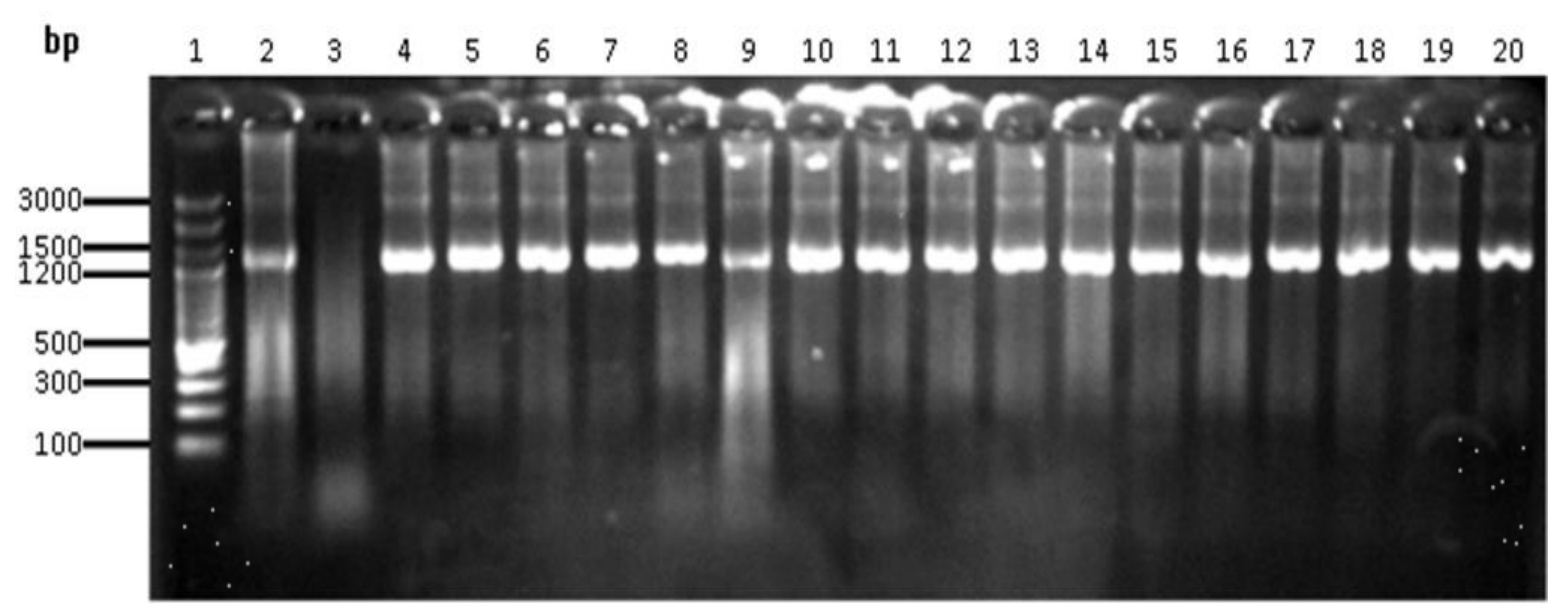

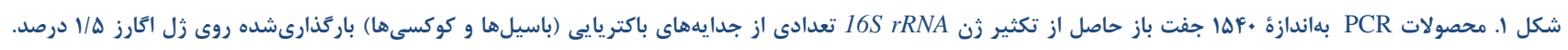

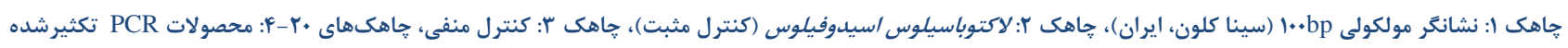
از جدايههاى مختلف باكترى هاى اسيدلاكتيك. 


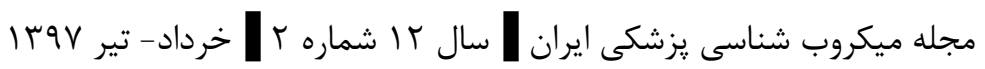

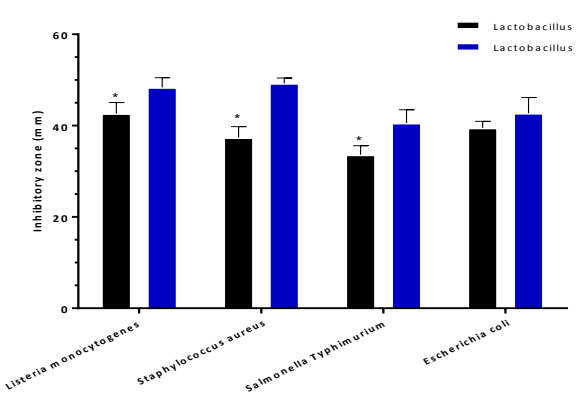

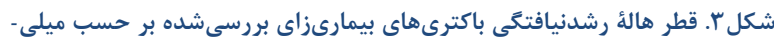

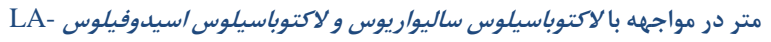

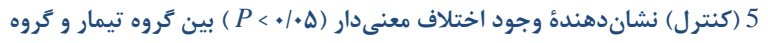
كنترل است.

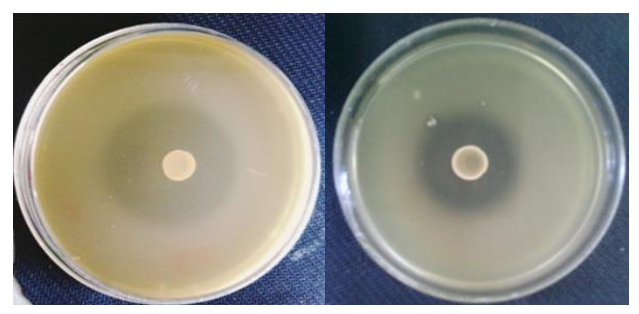

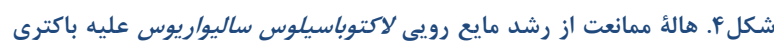
كرم منفى (شريشيا كلى) (سمت راست). باكترى كرم مثبت (استافيلوكوكوس

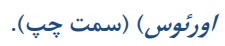

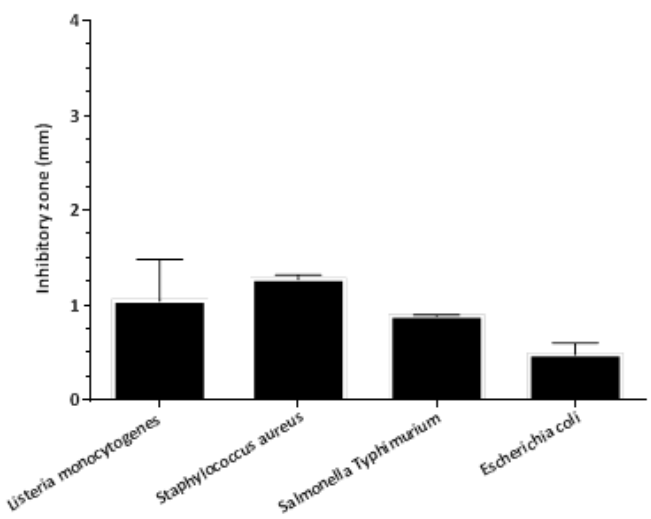

شكله. قطر هالئ رشدنيافتكى باكترىهاى بيمارىزا بر حسب ميلىمتر در مواجهه

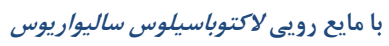

هيدروفوبيستى لاكتوباسيلوس ساليواريوس

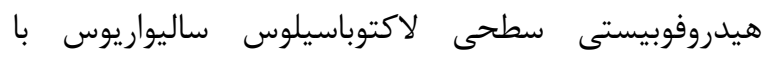
استفاده از اتصال به كزيلن و تولئن در شكل 9 آورده شده است.

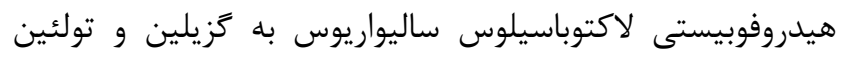

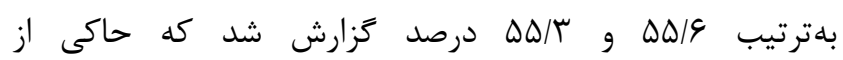
هيدروفوبيستى متوسط و مناسب جدايه بود.
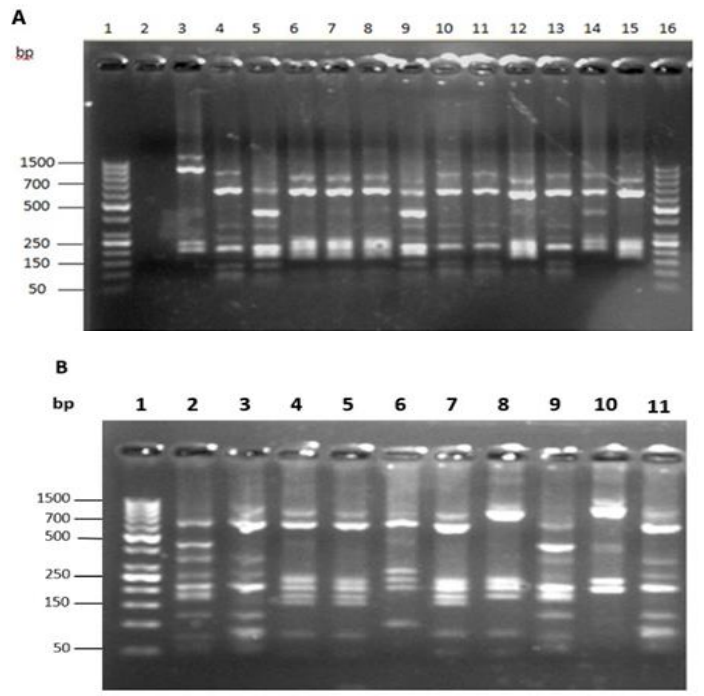

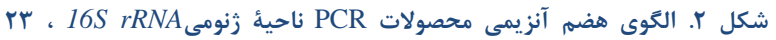

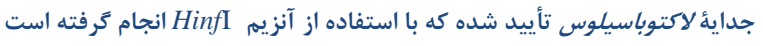

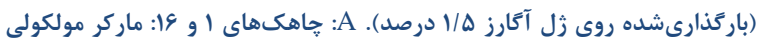

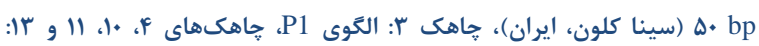

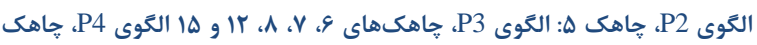

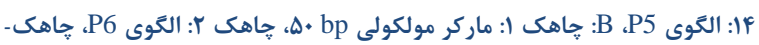

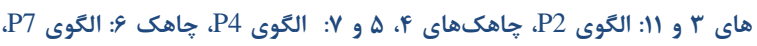

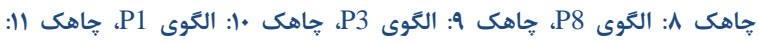

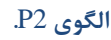

\section{فعاليت ضدميكروبى لاكتوباسيلوس ساليواريوس}

توانايى مهار رشد جدائ لاكتوباسيلوس ساليواريوس و و لاكتوباسيلوس /سيدوفيلوس LA5 روى باكترىهاى بيمارىزا كه

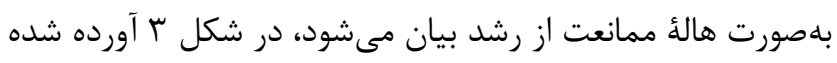

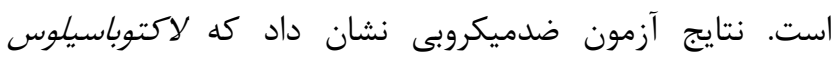
ساليواريوس اثر مهارى روى باكترىهاى ليستريا مونوسيتوزنز،

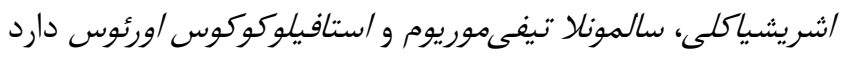

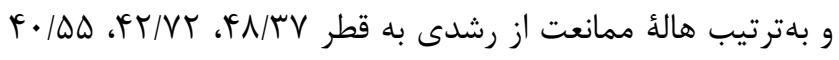

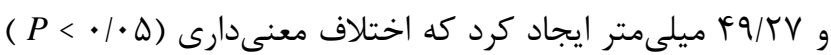

با باكترى استاندارد لاكتوباسيلوس /سيدوفيلوس LA-5 داشت.

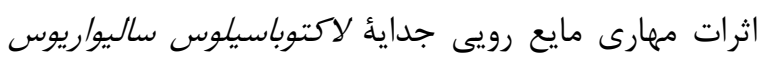

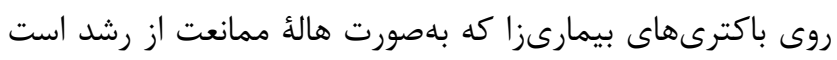

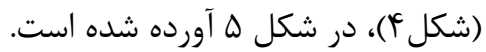


نتايج بررسى Aziz و همكاران (9 ...') روى باكترىهاى

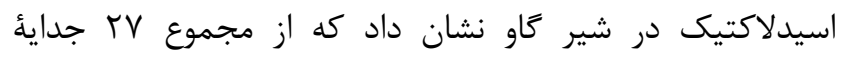
رشديافته در محيط MRS، با استفاده از شناسايى بيوشيميايى، داني،

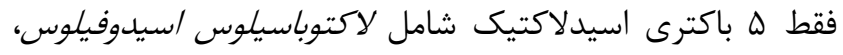

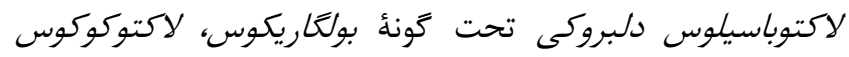

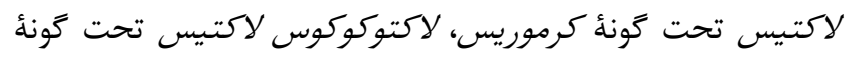

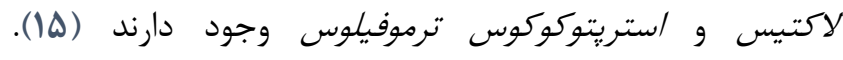

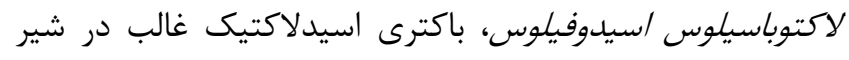

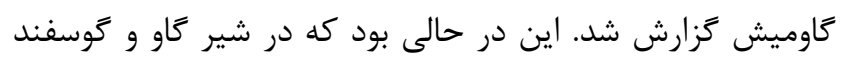

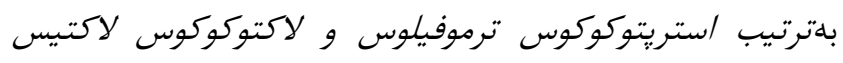

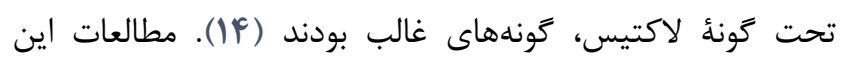

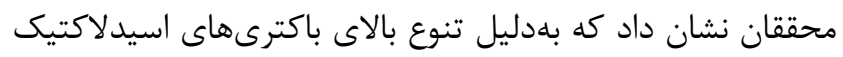

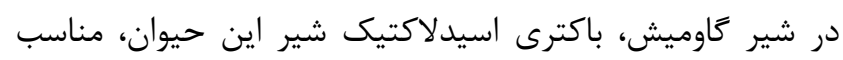

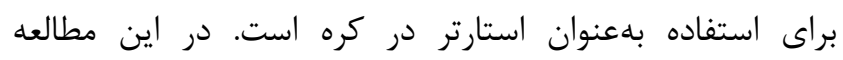

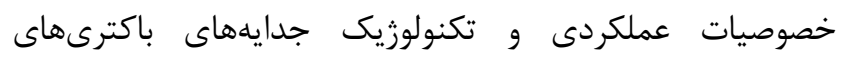
اسيدلاكتيك بررسى نشد (IF). بررسىهاى مولكولى عاضى در مطالعأ حاضر نشان داد از تعداد كل باكترىهاى اسيدلاكتيك كوكوسى،

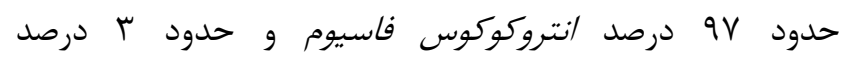

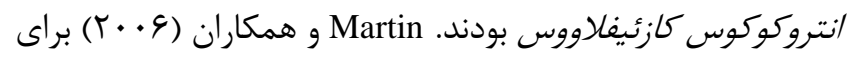

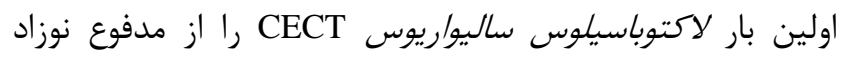

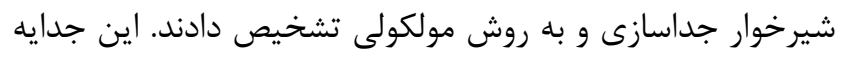

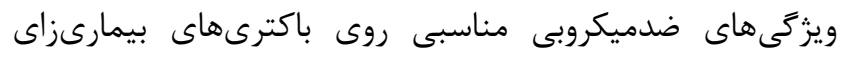

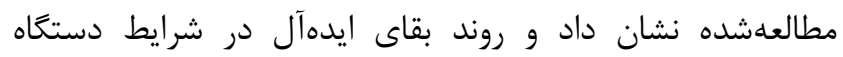

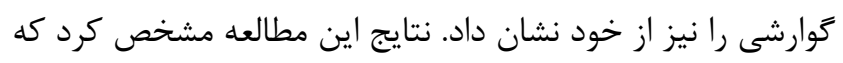

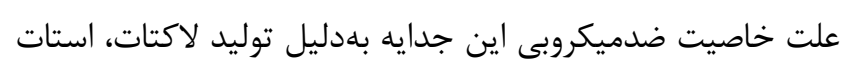

$$
\text { و يراكسيد هيدروزن است (1). }
$$

توانايى در مهار رشد باكترىهاى فسادزا و بيمارىزا از ماز مهرم-

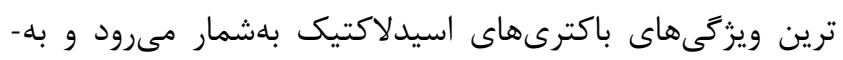

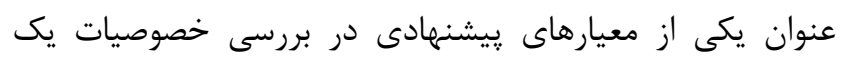

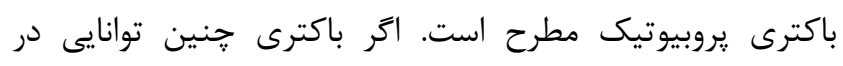

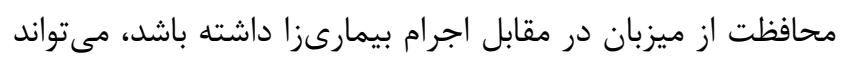

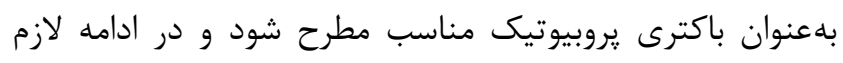

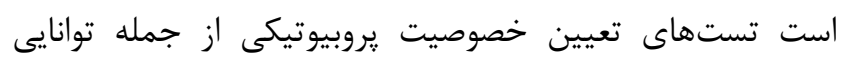

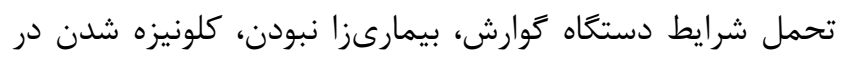

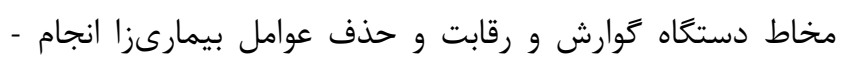

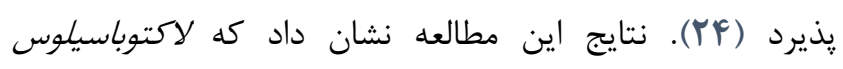

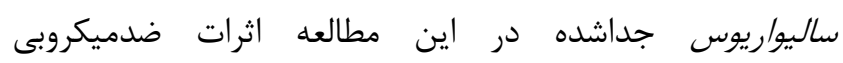

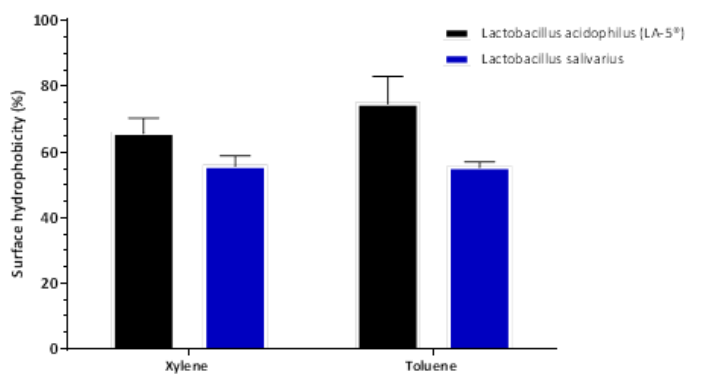

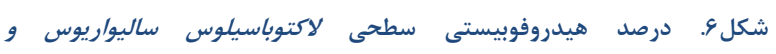
لاكتوباسيلوس اسيدوفيلوس LA-5 (نمونهُ كنترل) با استفاده از تزيلن و تولئن.

$$
\text { بحث و نتبجه تيبرى }
$$

باتوجه به اينكه جزئيات كاملى در زمينهُ جداسازى باكترى - باكئ

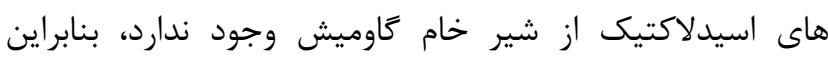

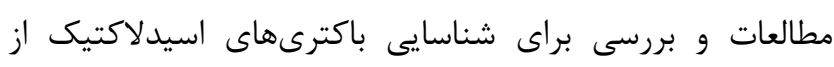

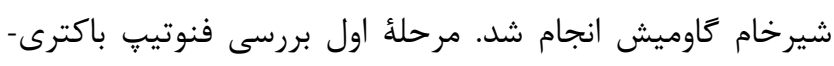

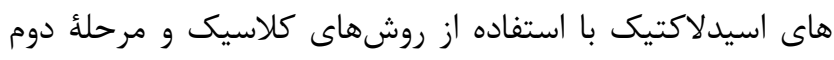

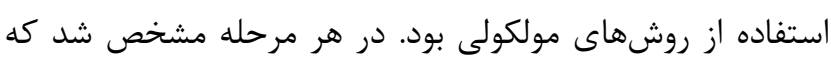
تعداد جدايههاى كوكسى بيشتر از باسيل بودي

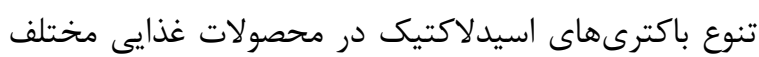

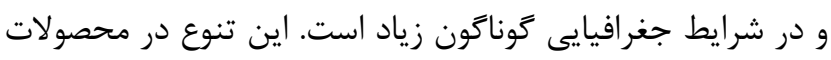

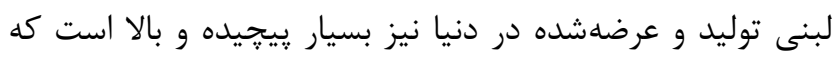
مى تواند انغيزهاى براى غربال

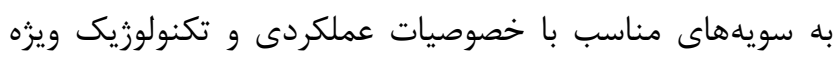

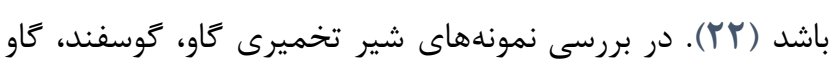

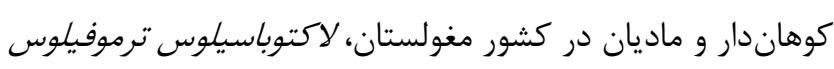

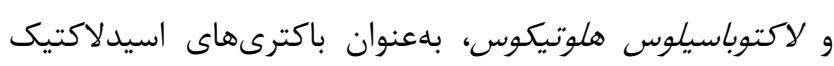
غالب كزارش شدند (Tr). در مطالعهاى كه در سال

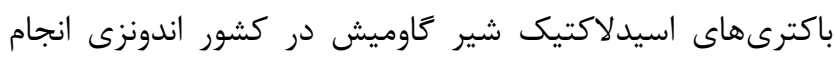

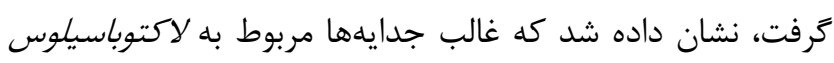

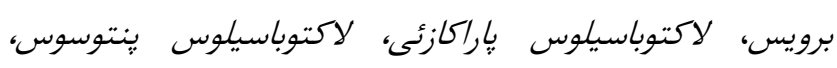

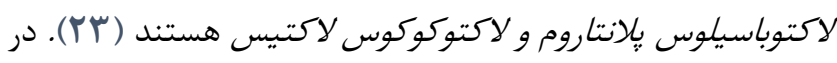

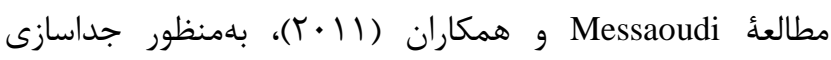
باكترىهاى اسيدلاكتيك از مدفوع مرغ، اكثريت جدايهها متعلق

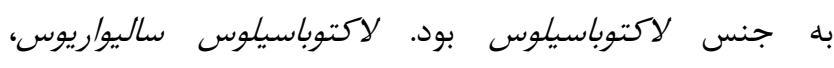
4/4/4 ادرصد كل باسيلوسهاى جداشده را به خود اختصاص داد. سه سويأ مختلف لاكتوباسيلوس ساليواريوس ( SMXD51, ) (MMS122, MMS151 كمبيلوباكتر ثزونى و كميِيلوباكتر كلى داشت. اين ويزَّى بهدليل توليد باكتريسوين از سوى اين سويهها كزارش شد (r) (I). 
لاكتوكوكوس، لوكونستوك، لاكتوباسيلوس و إْانكوكوس قرار

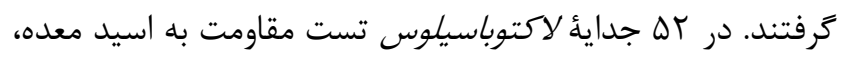
نمكهاى صفراوى، بررسى خصوصيات ضدميكروبى و مقاومت به به آنتىبيوتيك انجام يذيرفت كه نتايج وجود ويزَّى يروبيوتيكى مناسب در سه كونه را نشان داد (YV) مطالعات مختلفى دربارة بررسى ويزگى هاى ضدميكروبى باكترىهاى اسيدلاكتيك صورت گرفته كه در برخى از آنها علت

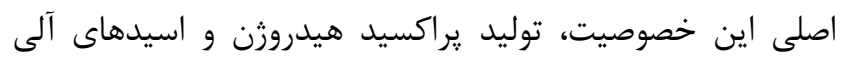

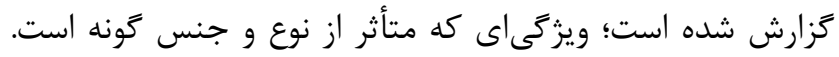
يكى از دلايل مهم ويزگى ضدميكروبى باكترىهاى اسيدلاكتيك استى مربوط به توليد تركيبات شبه باكتريوسين است. باكتريوسينها،

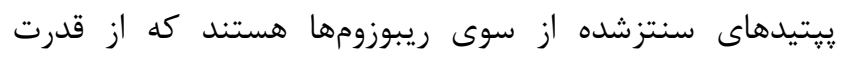
ضدميكروبى بالايى برخوردارند. طيف وسيعى از باكترىها از جمله

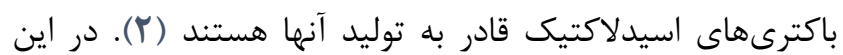

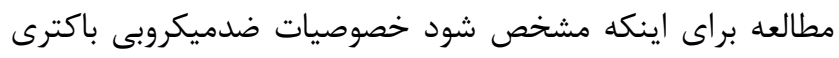
مربوط به كدام تركيب باكترى است، مايع رويى باكترى تهيه مئه و

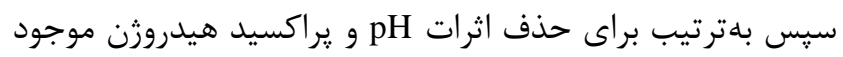
در مايع رويى از سود (رساندن pH به ميزان خنثى) و كاتالاز استفاده شد. در نتيجه، عمده تركيب ضدميكروب موجود در مرائ مايع رويى، تركيبات شبه باكتريوسين تصور مىشود. نتايج مطالعئ حاضر نشان داد كه بخشى از اثرات ضدميكروبى جدائ لاكتوباسيلوس مربوط به تركيبات شبه باكتريوسين است، جرا كه إنهان

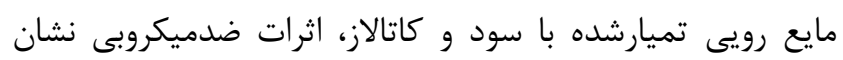
داد. بيشترين اثر ضدميكروبى پاليده بر عليه باكترى كرم مثبت

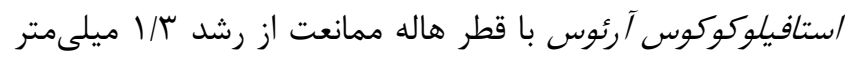

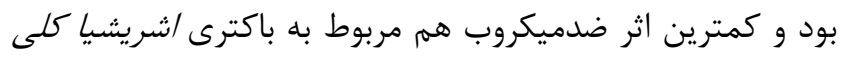

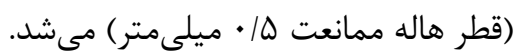
بلهور كلى، فعاليت ضدميكروبى باكتريوسينها عليه

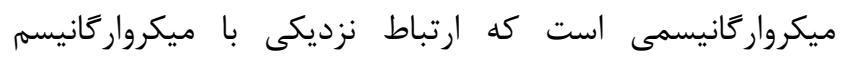

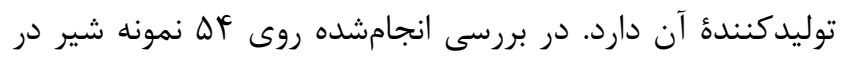

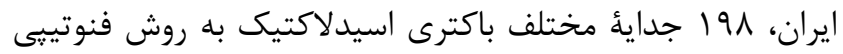

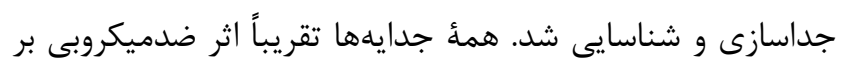

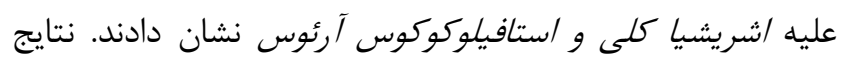

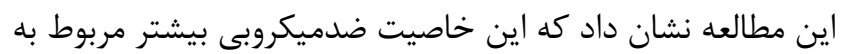

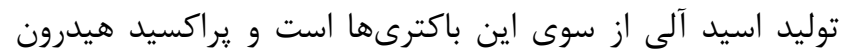

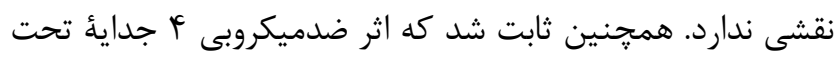

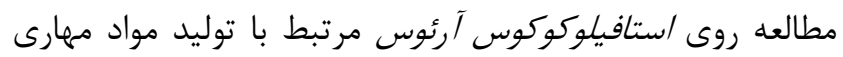

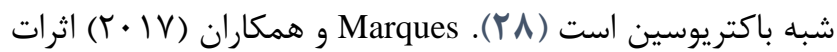

منحصربهفردى دارد؛ بهطورى كه در مقايسه با لاكتوباسيلوس

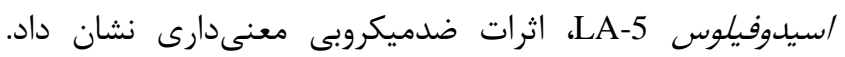
بيشترين اثر ضدميكروبى جدائ لاكتوباسيلوس ساليواريوس بلهترتيب در استافيلوكوكوس آرئوس (

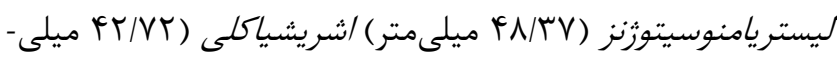

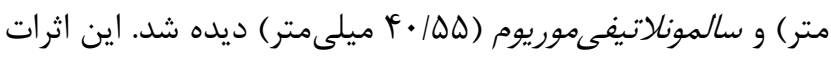

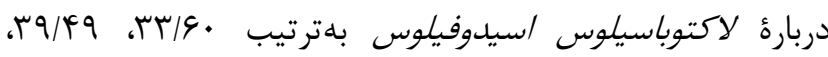
د ST/GD و TV/TV در مقايسه با كرم منفىها، حساسيت بيشترى نسبت به جدائه

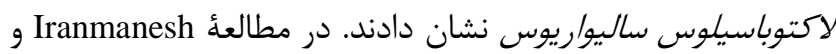

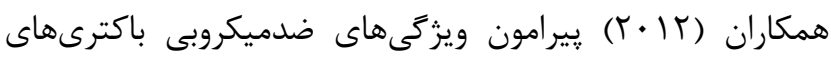

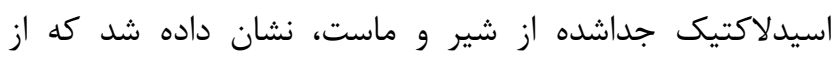

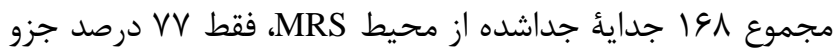

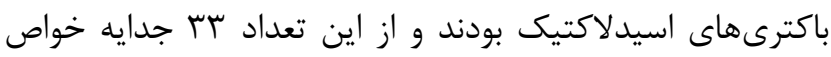

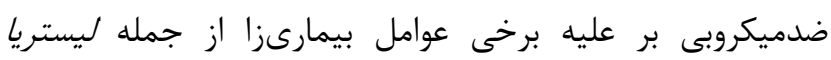

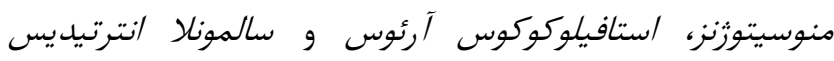

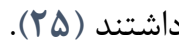

Karami

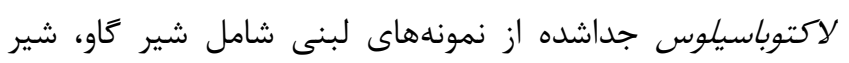
Fاوميش، ينير و ماست عليه /ستافيلوكوكوس /ورئوس، باسيلوس آناسي

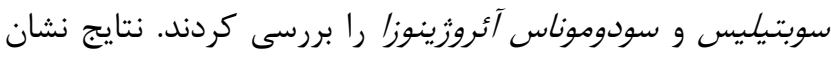

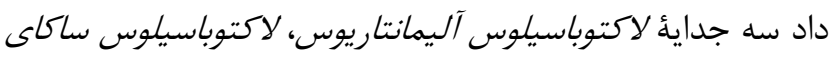

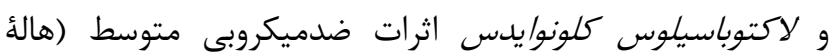

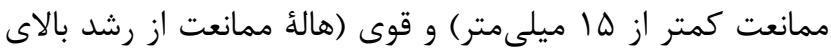

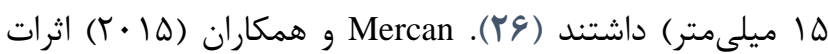

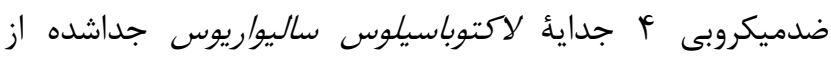

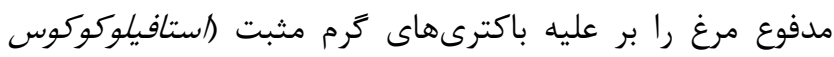
اورئوس و باسيلوس سرئوس) و منفى (شريشياكلى، سالمونلا

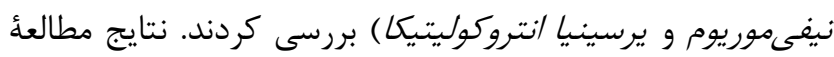

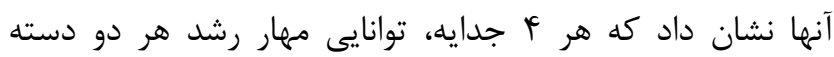

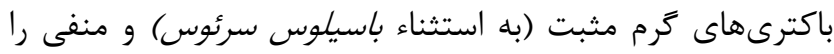

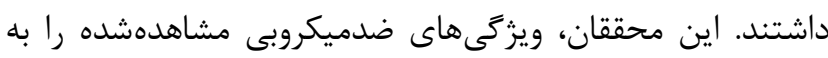

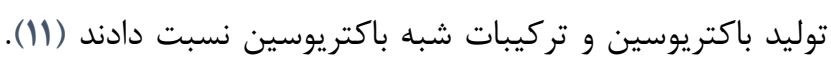

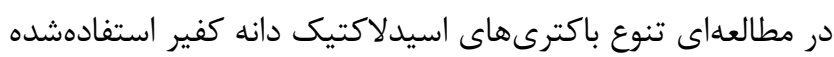
در كشور برزيل با هدف جداسازى جدائ لاكتوباسيلوس باكيا

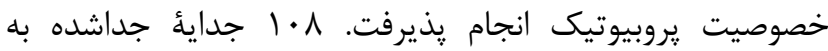

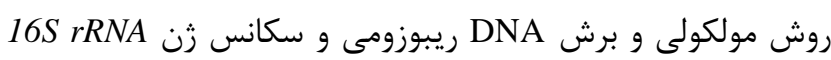

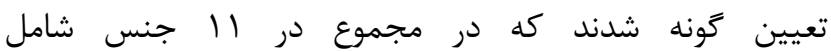


از آنجا كه جداسازى و غربال ميكرواركانيسمها از منابع

طبيعى، روشى مؤثر براى بهدست آوردن سويههاى مفيد با

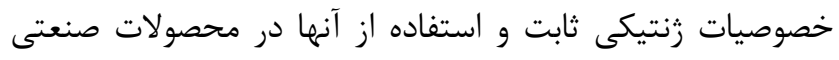

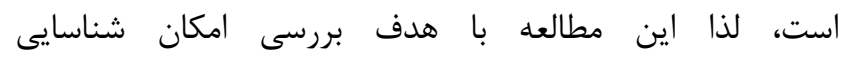
لاكتوباسيلوس ساليواريوس بهعنوان باكترى ڤيروبيوتيك بالقوه

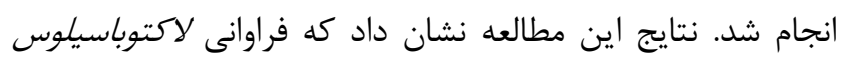
بهعنوان يكى از جنسهاى مهمم باكترىهاى اسيدلاكتيك در شير

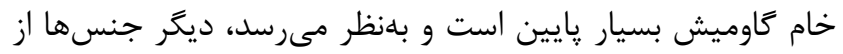

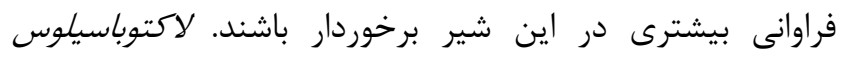

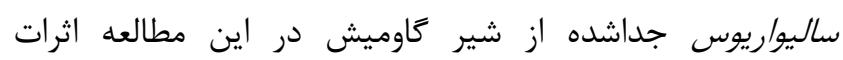

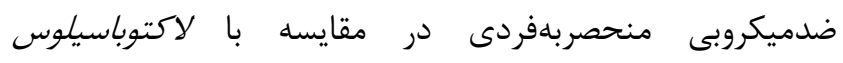

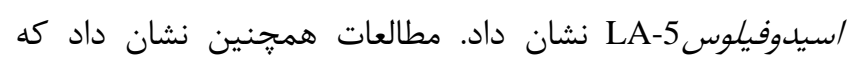
بخشى از اين خصوصيت مربوط به تركيبات شبه باكتريوسين است دئ دان

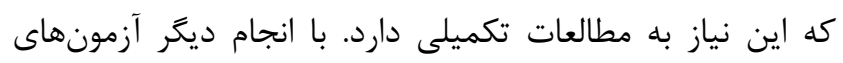

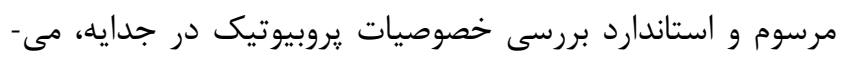
توان از جدائٔ فعلى بهعنوان يك يروبيوتيك جديد در صردئ صنايع مختلف از جمله صنايع لبنى استفاده كرد.

$$
\text { سياسگزارى }
$$

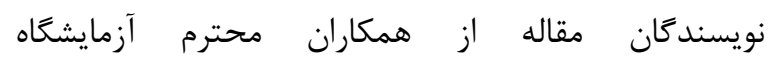

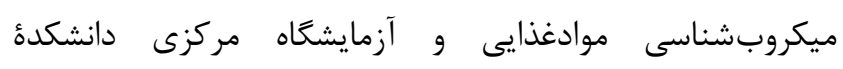

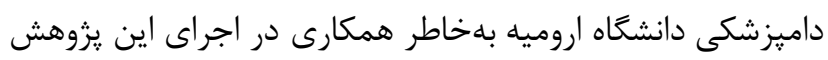

$$
\text { كمال امتنان را بهعمل مى آورند. }
$$

$$
\text { تعارض منافع }
$$

بين نويسند

\section{References}

1. Perin LM, Miranda RO, Todorov SD, Franco BDGdM, Nero LA. Virulence, antibiotic resistance and biogenic amines of bacteriocinogenic lactococci and enterococci isolated from goat milk. Int J Food Microbiol. 2014;185:121-6. https://doi.org/10.1016/j.ijfoodmicro.2014.06.001 PMID:24960293

2. Yang E, Fan L, Jiang Y, Doucette C, Fillmore S. Antimicrobial activity of bacteriocin-producing lactic acid bacteria isolated from cheeses and yogurts. AMB Express. 2012;2(1):48. https://doi.org/10.1186/2191-0855-2-48 PMID:22963659 PMCID:PMC3488010

3. de Almeida Júnior WLG, Ferrari ÍdS, de Souza JV, da Silva CDA, da Costa MM ,Dias FS. Characterization and evaluation of lactic acid
مواد شبه باكتريوسين لاكتوباسيلوس كورواتوس P99 را بر ليستريا

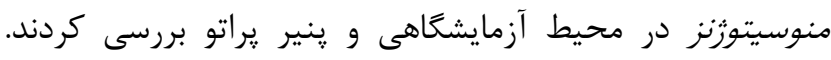

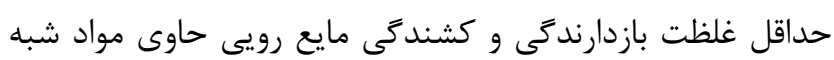

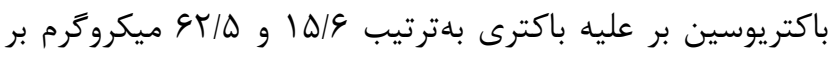

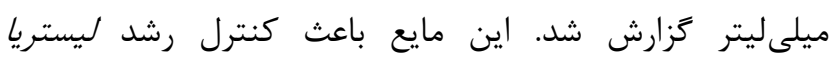
منوسيتوزنز در ينير شد (F). يكى از معيارهاى باكترىهاى يروبيوتيك، مرتبط با توانايى باكترسى در كلونيزه شدن در دستخاه گوارش انسان و حيوان است.

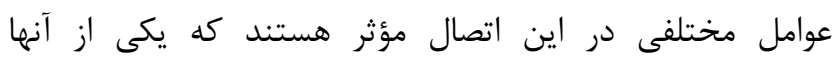
هيدروفوبيستى سطح باكترى است. هرجقدر باكترى هيدروفوب باشد، توانايى بيشترى در اتصال به سطوح دارد. هيدروفوبيستى بإيسى سطحى باكترى، متأثر از محتواى غشاء سيتوِلاسمى باكى باكترى است. باكترىهايى با قدرت هيدروفوبى بالا، كانديداهاى مناسبى براى بـى

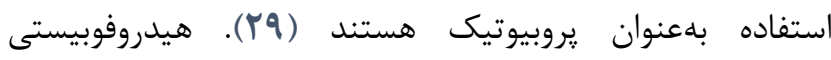

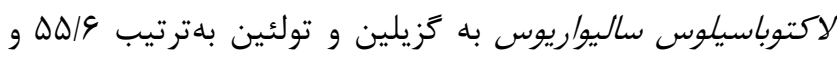

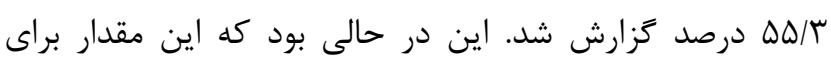

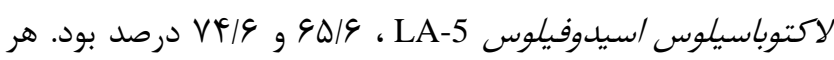

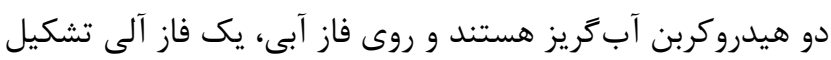

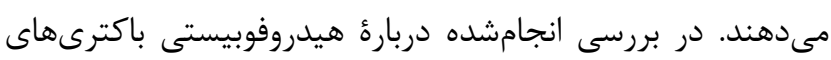

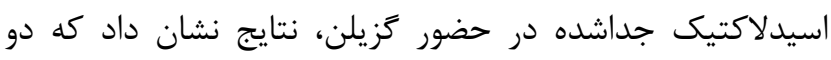

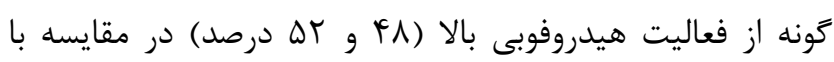
سويه استاندارد (YV درصد) برخوردار بودند (Y). نتايج مطالعه حاضر نشان داد كه هيدروفوبيسيتى سطحى جدائُ لاكتوباسيلوس، اختلاف معنى دارى با باكترى استاندارد ندارد.

bacteria isolated from goat milk. Food Control. 2015;53(0):96-103. https://doi.org/10.1016/j.foodcont.2015.01.013

4. Marques JdL, Funck GD, Dannenberg GdS, Cruxen CEDS, Halal SLME, Dias ARG, et al. Bacteriocinlike substances of Lactobacillus curvatus P99: characterization and application in biodegradable films for control of Listeria monocytogenes in cheese. Food Microbiol. 2017;63:159-63. https://doi.org/10.1016/j.fm.2016.11.008 PMID:28040164

5. Bernardeau M, Vernoux JP, Henri-Dubernet S, Guéguen M. Safety assessment of dairy microorganisms: The Lactobacillus genus. Int $\mathbf{J}$ Food Microbiol. 2008;126(3):278-85. https://doi.org/10.1016/j.ijfoodmicro.2007.08.015 PMID: 17889388 
6. Jeronymo-Ceneviva A, de Paula A, Silva L, Todorov S, Franco BM, Penna A. Probiotic Properties of Lactic Acid Bacteria Isolated from Water-Buffalo Mozzarella Cheese. Probiotics Antimicro Prot. 2014;6(3-4):141-56. https://doi.org/10.1007/s12602-014-9166-2 PMID:25117002

7. Rooney ML. Introduction to active food packaging technologies. In: Han J, editor. Innovations in food packaging. Amsterdam: Elsevier Ltd; 2005. https://doi.org/10.1016/B978-012311632-1/500371

8. Martín R, Jiménez E, Olivares M, Marín ML, Fernández L, Xaus J, Rodríguez JM. Lactobacillus salivarius CECT 5713, a potential probiotic strain isolated from infant feces and breast milk of a mother-child pair. Int $\mathbf{J}$ Food Microbiol. 2006;112(1):35-43.

https://doi.org/10.1016/j.ijfoodmicro.2006.06.011 PMID:16843562

9. Sun E, Ren F, Liu S, Ge S, Zhang M, Guo H. et al. Complete genome sequence of Lactobacillus salivarius Ren, a probiotic strain with anti-tumor activity. J Biotechnol. 2015;210:57-8. https://doi.org/10.1016/j.jbiotec.2015.06.399 PMID:26133929

10. Luo Z, Gasasira v, Huang Y, Liu D, Yang X, Jjiang $\mathrm{S}, \mathrm{Hu} \mathrm{W}$. Effect of Lactobacillus salivarius $\mathrm{H}$ strain isolated from Chinese dry-cured ham on the color stability of fresh pork. Food Sci Hum Wellness. 2013;2(3-4):139-45.

https://doi.org/10.1016/j.fshw.2013.11.001

11. Mercan E, İspirli H, Sert D, Yilmaz mT, Dertli E. Impact of exopolysaccharide production on functional properties of some Lactobacillus salivarius strains. Arch Microbiol. 2015;197(9):1041-9.

https://doi.org/10.1007/s00203-015-1141-0 PMID:26267164

12. Messaoudi S, Kergourlay G, Rossero A, Ferchichi M, Prévost H, Drider D, Manai M, Dousset X. Identification of lactobacilli residing in chicken ceca with antagonism against Campylobacter. Int Microbiol. 2011;14(2):103-10. PMID:22069154

13. Zacharof MP, Lovitt RW. Bacteriocins produced by lactic acid bacteria a review article. APCBEE Procedia. https://doi.org/10.1016/j.apcbee.2012.06.010

14. Chowdhury A, Hossain MN, Mostazir NJ, Fakruddin M, Md. Billah M. Screening of Lactobacillus spp. from Buffalo Yoghurt for Probiotic and Antibacterial Activity. J Bacteriol Parasitol. 2012;3(8):1-5. https://doi.org/10.4172/2155-9597.1000156
15. Aziz T, Khan H, Bakhtair SM, Naurin M. Incidence and relative abundance of lactic acid bacteria in raw milk of Buffalo, Cow and Sheep. J Anim Plant Sci. 2009;19(4):168-73.

16. Iranmanesh $\mathrm{M}$, Ezzatpanah $\mathrm{H}$, Mojgani $\mathrm{N}$. Antibacterial activity and cholesterol assimilation of lactic acid bacteria isolated from traditional Iranian dairy products. LWT - Food Sci Technol. 2014;58(2):355-9. https://doi.org/10.1016/j.lwt.2013.10.005

17. Aljanabi SM, Martinez I. Universal and rapid saltextraction of high quality genomic DNA for PCRbased techniques. Nucleic Acids Res. 1997;25(22):4692-3. https://doi.org/10.1093/nar/25.22.4692

18. Scarpellini M, Mora D, Colombo S, Franzetti L. Development of genus/species-specific pcr analysis for identification of carnobacterium strains. Curr Microbiol. 2002;45(1):24-9. https://doi.org/10.1007/s00284-001-0043-3 PMID:12029523

19. Awaisheh SS, Ibrahim SA. Screening of antibacterial activity of lactic acid bacteria against different pathogens found in vacuum-packaged meat products. Foodborne Pathog Dis. 2009;6(9):1125-32.

https://doi.org/10.1089/fpd.2009.0272 PMID:19694551

20. Buncic S, Avery SM, Moorhead SM. Insufficient antilisterial capacity of low inoculum Lactobacillus cultures on long-term stored meats at $4{ }^{\circ} \mathrm{C}$. Int $\mathrm{J}$ Food Microbiol. 1997;34(2):157-70. https://doi.org/10.1016/S0168-1605(96)01181-6

21. Sahoo TK, Jena PK, Nagar N, Patel AK, Seshadri $S$. In vitro evaluation of probiotic properties of lactic acid bacteria from the gut of labeo rohita and catla catla. Probiotics Antimicro Prot. 2015;7(2):126-36. https://doi.org/10.1007/s12602-015-9184-8 PMID:25634754

22. Yu J, Wang WH, Menghe BLG, Jiri MT, Wang HM, Liu WJ, et al. Diversity of lactic acid bacteria associated with traditional fermented dairy products in Mongolia. J Dairy Sci. 2011;94(7):3229-41. https://doi.org/10.3168/jds.2010-3727 PMID:21700007

23. Rizqiati H, Nurwantoro, Mulyani S, Febrisiantosa A. Isolation and identification of lactic acid bacteria from pampangan buffalo milk of south Sumatera, Indonesia. Int J Pharm Biol Sci. 2016;2(4):1-12.

24. Anandharaj M, Sivasankari B. Isolation of potential probiotic Lactobacillus oris HMI68 from mother's milk with cholesterol-reducing property. J Biosci 
Bioeng.

2014;118(2):153-9.

https://doi.org/10.1016/j.jbiosc.2014.01.015

PMID:24613732

25. Iranmanesh M, Ezzatpanah H, Mojgani N, Karimi Torshizi MA, Aminafshar M, Mohamad Maohamadi M. Isolation of lactic acid bacteria from ewe milk, traditional yoghurt and sour buttermilk in Iran. European J Food Res Rev. 2012;2(3):79-92.

26. Karami S, Roayaei M, Hamzavi H, Bahmani M, Hassanzad-Azar H, Leila M, et al. Isolation and identification of probiotic Lactobacillus from local dairy and evaluating their antagonistic effect on pathogens. Int J Pharma Investig. 2017;7(3):13741. $\quad$ https://doi.org/10.4103/jphi.JPHI_8_17 PMID:29184826 PMCID:PMC5680649

27. Zanirati DF, Abatemarco Jr M, Sandes SHdC, Nicoli JR, Nunes ÁC, Neumann E. Selection of lactic acid bacteria from Brazilian kefir grains for potential use as starter or probiotic cultures. Anaerobe. 2015;32:70-6.

https://doi.org/10.1016/j.anaerobe.2014.12.007 PMID:25542841

28. Taheri P, Samadi N, Khoshayand MR, Fazeli MR, Jamalifar H, Ehsani MR. A study on the antibacterial activity of lactic acid bacteria isolated from traditional iranian milk samples. Int J Agri Sci Res. 2011;2(1):27-34.

29. Li Q, Liu X, Dong $M$, Zhou J, Wang Y. Aggregation and adhesion abilities of 18 lactic acid bacteria strains isolated from traditional fermented food. Int J Agri Policy Res. 2015;3(2):84-92. 